\title{
Legal Reformation of Tax Court in Indonesia: Reforming Legal Culture, Institutional and Legislative Aspects
}

\author{
Budi Ispriyarso ${ }^{1, *}$, Athasius P. Bayuseno ${ }^{1}$ and Harlida Abdul Wahab ${ }^{2}$ \\ ${ }^{1}$ Faculty of Law, Diponegoro University, Semarang, Indonesia \\ ${ }^{2}$ Universiti Utara Malaysia, Malaysia
}

\begin{abstract}
This research is motivated by the many weaknesses that exist in the Ppajak court in Indonesia. Therefore, this research needs to be carried out with the aim that the tax court in the future will be better, more certain in law, and just. The problem is the reason for reforming the tax court in Indonesia and the way to reform the law on the tax court in Indonesia. The research method used is a statutory, historical, and comparative approach. The result of his research is that the tax court in Indonesia must be reformed because it contains many weaknesses. Furthermore, the findings show that tax court reform must be carried out from the aspects of legislation, institutional and legal culture. Based on the statutory aspect, synchronization of laws must be carried out. Based on the institutional aspect, institutional improvement must be carried out. Based on the aspect of legal culture, this must be done by increasing the morale of the parties. The novelty of this research is that the tax dispute settlement model is found after the tax court becomes a special court within the state administrative court. In conclusion, the tax court in Indonesia still contains many weaknesses, so it must be reformed immediately.
\end{abstract}

Keywords: Tax court, legal reform, legislation, legal institutions, legal culture, Indonesia.

\section{INTRODUCTION}

According to the conventions of Article 1 paragraph (3) of the 1945 Constitution of the Republic of Indonesia, it declares the State of Indonesia shall be a state based on the rule of law. Indonesia is a nation where every law executed by the Government affairs must be relied on the applicable law (Ridwan, 2011). In-state law, law enforcement must be done consistently, and the law must become a commander. Up to now, people have realized that the prolonged multidimensional crisis has happened in Indonesia because the law has been failed to become a commander (Tyesta et al., 2020). The law is expected to be a formula for curing "the sickness of the nation" resulting from the prolonged crisis, but the law's implementation in practices runs unexpectedly. Presumably, law enforcement was performed unsatisfactorily (Pudyatmoko, 2013). Concerning law enforcement, the institutions of law enforcement are required. For law enforcement in a country, law enforcement authorities are needed. Moreover, the existence of these law enforcement institutions to carry out law enforcement would play significant roles in giving sanctions to those who break the law (Horodnic, 2018; Indarti, 2020). These institutions may be judicial . In-state law, a judicial institution becomes very important because, in history, there have always been

\footnotetext{
*Address correspondence to this author at the Faculty of Law, Diponegoro University, Jl. Prof. Soedarto, S.H. Tembalang, Semarang, Central Java 50275, Indonesia; Tel: +62-2476918201; Fax: +62-247691820;

E-mail: budiispriyarso@lecturer.undip.ac.id
}

parties, both state / governmental administration and the people who violated the provisions of the law (Afdol \& Setjoatmadja, 2015).

One of the justice institutions in Indonesia is the Tax Court, which has been established according to Law No. 14 of 2002 concerning Tax Courts (hereinafter referred to as the Tax Court Law). This tax court similar to other justice institutions has its procedural law which has been regulated in the Tax Court Law (Saidi, 2011). For instance, Civil Law has its civil procedural law and criminal law as well. Here, Civil Law and Criminal Law separate material criminal law and formal criminal law, which are regulated in two different laws (Saraswati et al., 2019). In contrast, the tax law does not separate material tax law and tax law formal, which are regulated in one law. Correspondingly, the tax court has the authority to examine and provide decisions on tax disputes. It is emphasized in articles according to the Tax Court Law that the tax dispute include a legal action between the Taxpayer or the Tax Insurer and the authorized official in a matter of an issued decision for submitting an appeal or filing a lawsuit to the Tax Court based on statutory regulations, including Lawsuit over billing based on the Billing Law with Forced Taxes (Article 1(5) of the Tax Court Law). Based on data from the Ministry of Finance's Tax Court Secretariat, the number of tax dispute resolutions in the period of 20122016 is presented in Table 1.

Thus, the existence of a Tax Court, according to Law No. 14 of 2002 is intended to strengthen the existing judicial institution (BPSP) and also to provide 
Table 1: Tax Dispute Settlement in the Years of 2012-2016

\begin{tabular}{|c|c|c|c|c|c|c|c|}
\hline No & Decision results & 2012 & 2013 & 2014 & 2015 & 2016 & Total \\
\hline 1 & Revocation & 75 & 81 & 95 & 178 & 1352 & 1781 \\
\hline 2 & Unacceptable & 1037 & 1013 & 854 & 1187 & 1774 & 5865 \\
\hline 3 & Decline & 1700 & 1929 & 2438 & 2294 & 2878 & 11239 \\
\hline 4 & Adding tax to be paid & 3 & 2 & 1 & 13 & 8 & 27 \\
\hline 5 & Granting a part of the request & 732 & 1003 & 1430 & 1217 & 1346 & 5728 \\
\hline 6 & Granting a whole request & 2530 & 3276 & 3991 & 4049 & 5367 & 19213 \\
\hline \multirow[t]{2}{*}{7} & Cancellation & 476 & 73 & 37 & 94 & 127 & 807 \\
\hline & Total & 6553 & 7377 & 8846 & 9032 & 12852 & 44659 \\
\hline
\end{tabular}

legal certainty and justice, in fact, however, these conditions in the tax courts have been not achieved as expected (Ispriyarso, 2015). Accordingly, the weakness found in the tax courts based on Law No. of 14, 2002 can relate to juridical controversies between the provisions of Law No. 14 of 2002 and other laws, namely the dualism of Tax Court guidance, the weak supervision, the majority of judges from the Directorate General of Taxes and Customs, the absence of appeal and cassation, the imbalance between the taxpayer, and the tax authorities in litigation in the Tax Court. These weaknesses of the tax court make legal uncertainty and injustice. Even the weakness of the Tax Court may provide opportunities for tax manipulation. This condition became obvious in an increase in the case of the "taxation mafia" which was revealed and became public attention. The potential tax revenue (tax gap) due to bribery, smuggling, and other crimes reaches IDR 300 trillion per year. This number is equivalent to $34.8 \%$ of the potential maximum tax revenue that should be received by the nation, which is IDR 860 trillion per year. Therefore, some of the weaknesses found in the Tax Court must be reformed immediately to achieve a better Tax Court in the future. The problem in this research is regarding the reasons for the reform of the tax court in Indonesia and how to carry out legal reform of the tax court from the aspects of the institution, legislation, and legal culture.

\section{LITERATURE REVIEW}

Tax according to Soemitro (1977), is an engagement between the taxpayer and the Government arising from the law that obligates anyone meeting the requirements (tatbestand) to pay a certain amount of money to the state, which is coercive without receiving compensation (counter-achievement) directly (Juli \& Sariono, 2014). Moreover, tax law covers the overall legal regulations governing the legal relationship between the government as a tax collector and the people as taxpayers. Generally, tax law can be divided into formal tax law and material tax law. First, the formal tax law includes regulation on how material tax law can be implemented or enforced. One of the tax laws governing tax law enforcement is Law No. 14 of 2012 concerning Tax Courts. Here the Tax Court is a judicial body that exercises judicial power for taxpayers or tax bearers who seek justice against tax disputes. The legal basis for a Tax Court in Indonesia is Law No. 14 of 2002 concerning Tax Courts. This institution has the authority to decide cases regarding tax disputes. Article 1 point 5 of this law describes the definition of tax disputes as disputes arising in the field of taxation between the taxpayer or tax guarantor and the authorized official as a result of the issuance of a decision that can be appealed or appealed to the Tax Court based on tax legislation, including a lawsuit over billing based on the Forced Tax Act.

According to the provisions of Article 1 point 5 of the Tax Court Law, it can be inferred from the text that the Tax Court possesses a duty and authority to examine tax disputes, especially appeals and lawsuits. Particularly, the authority of the Tax Court in examining and deciding tax disputes covers all types of taxes levied by the Central Government (Customs and Excise), and Local Governments, based on the applicable laws and regulations. At present, the Tax Court is a result of the improvement of the former tax court institution. Since 1959, the government has owned a Tax Court body, namely the Tax Advisory Council (MPP) which was subsequently supplanted by the Tax Dispute Resolution Board (BPSP) in 1997. However, this Board has not become a judicial body that finally culminates in the Supreme Court. Consequently, a Tax Court was founded in 2002, when 
the tax court body was needed to be worthy of the judicial power system in Indonesia and at the same time it can produce justice and legal certainty in settling tax disputes. However, this goal has not yet been achieved, because the Tax Court formed under Law No. 14 of 2014 still contains many weaknesses.

\section{METHOD}

As previously explained, the current tax court contains many weaknesses. These weaknesses include the dualism of guidance, the uncertainty of the position of the Tax Court in the judicial system in Indonesia, the absence of appeals and cassations, the imbalance of positions in the trial process at the Tax Court. Therefore, the Tax Court must be reformed so that these weaknesses can be eliminated. In reforming the Tax Court, it is carried out from an institutional aspect, a statutory aspect, and a legal culture aspect. It is hoped that this legal reform of the tax court, it will produce a better tax court, which is more certain in law and just.

In connection with the problems, the method used in this study is the normative juridical method, the main data source of which is from literature studies, with statutory, historical, and comparative approaches by mainly examining Law No. 14 of 2002 concerning Tax Courts. The legal theory used is the legal system theory proposed by Friedman (1975), which states that the legal system consists of a legal structure, a legal substance in terms of legislation and legal culture.

\section{RESULTS}

\subsection{Reform of Legal Culture}

Legal reform means a drastic change for the improvement of the field of law in a society or country. Legal reform has an important role in the building of institutional design through the establishment of the aspired legal state. For improving the legal material/substance it can be implemented several alternatives. One of them is by modifying the existing legal provisions to follow the development of awareness and legal needs that develop in society. In this regard, a comprehensive thorough repair of the Tax Court must be done for reforming the legal system of tax justice institutions in Indonesia. The legal reformation of the Tax Court should not only strengthen the institution but also matters relating to the tax court institution, namely the laws that govern it and aspects of its legal culture (Horodnic, 2018; Bruno, 2019).
Furthermore, the legal system theory was proposed by Friedman (1975) who states that the legal system includes three elements, namely legal structure, a legal substance, and legal culture. The legal structure presents a law enforcement agency as an institution that implements operating law. The legal substance is a regulation that serves as a reference for working the law enforcement agencies, whereas legal culture is embodied in the pattern of law enforcement behaviour (Filippin et al., 2013). Accordingly, the legal reforms to the Tax Court from the institutional aspect is suggested to be carried out through eliminating the dualism of the Tax Court supervision, by uniting its supervision (both judicial technical and organizational, administrative and financial) under the Supreme Court; providing the legal certainty for the status of the Tax Court at the Special Court for State Administrative Court; strengthening aspects of supervision; adding the Tax Courts in several regions.

\subsection{Institutional Reformation}

The status of the Tax Court based on Law No. 14 of 2002 does not fit with the justice system in Indonesia because its status is outside of the scope of four judicial regulated in the Judicial Power Act. To give legal certainty, the status of the Tax Court is within one of the court's scopes. In its latest development, the status of the Tax Court is in the scope of the Special Court within the State Administrative Court. The provisions provided by the Tax Court as a Special Court within the State Administrative Court cover in Article 27 paragraph (2) of Law No. 28 of 2007 on General provisions and rules for Taxation, Article 27 paragraph (1) of Law No. 48 of 2009 about Judicial Power and Article 9 A paragraph (1) of Law No. 51 of 2009 about State Administrative Court (PTUN). Therefore, for the sake of legal certainty in the status of the Tax Court, the provisions of Law No. 14 of 2012 must synchronize with the three Laws. Correspondingly, after the status of the Tax Court has included in the Special Court of the State Administrative Court, a proposed model needs to be developed for tax dispute settlements. The current practice of settling tax disputes is still implemented in the Tax Court according to Law No. 14 of 2002, on which the Tax Court does not recognize appeals and cassation. For this reason, the condition is unsuitable for the Judicial Power Law, and the amendments of the tax court are required.

Moreover, supervision strengthening is also needed as a basis for reformation. One of the weaknesses of 
the Tax Court is a lack of supervision. Implementation of supervision of the Tax Court so far is ineffective, due to the closed nature of the Tax Court system (Rumadan, 2012). The weak supervision provides growing a "tax court mafia" that results in adverse state finances. No appeal and cassation in the tax court system are one of the reasons for the weak supervision of the Tax Court. Legal remedies against tax court decisions can only be done with a Review of the Supreme Court (Juli \& Sariono, 2014) Moreover, no strict supervision format results in the rise of tax mafia practices that occur in Indonesia. The mafia can freely play in every case, including worries about playing with the judges in the Tax Court. Therefore, in the future, the tax court system must give an appeal and cassation. In addition to internal supervision carried out by the Supreme Court, the Judicial Commission performs external supervision. Based on Law No. 22 of 2004 about the Judicial Commission, the Judicial Commission has the authority to uphold honor and dignity and to support the conduct of judges (Article 13). Supervision of the behaviour of Tax Court judges is also the task of the Judicial Commission as an external supervisor as explained in the General Explanation of Law No. 3 of 2009 on the Second Amendment to Law No. 14 of 1985 on the Supreme Court, whereas the Supreme Court as the highest state court conducts the highest supervision of the judicial body underneath (makes up internal supervision). Article 32 of Law No. 32 of 2009 states that the Supreme Court as the highest state court of the state exercises the highest supervision administrating all judicial bodies below it in exercising judicial power. Also, the Supreme Court also carries the highest supervision for implementing administrative and financial tasks. This supervision includes supervision of the Tax Court under the Supreme Court.

\subsection{Reform of Legislative Aspect}

Reform in legislation can be carried out by synchronizing the Tax Court Law with statutory regulations. Synchronization of laws and regulations can be done vertically or horizontally. Based on vertical synchronization, there is the legal principle of ex superior derogat legi inferior; if there is a conflict/conflict between high and low laws and regulations, then the high ones should come first. Lower regulations must not conflict with higher laws and regulations. When examined from the vertical synchronization aspect of the Tax Court Law, there is a discrepancy between the Tax Court Law and the 1945 Constitution of the Republic of Indonesia. The discrepancy between the Tax Court Law and the 1945 Constitution of the Republic of Indonesia is related to the Tax Court position. The Tax Court's position is based on the 1945 Constitution and the Law on Judicial Power regulating a Special Court under the State Administrative Court. Meanwhile, in the provisions of the Tax Court Law, it is implied that the tax court's position is outside the four domains of the judiciary (not as a special court). It is a vertical inconsistency with the 1945 Constitution of the Republic of Indonesia. For example, the Tax Court Law needs to be revised by adding a provision that confirms that the Tax Court is under the State Administrative Court. It is like the Commercial Court which is affirmed under the General Court environment (Article 1(7) of Law No. 37 of 2004 concerning Bankruptcy and Postponement of Debt Payment Obligations).

The discrepancy between the Tax Court Law and other laws and regulations is with Law No. 48 of 2009 concerning Judicial Power, Law No. 51 of 2009 concerning the second amendment to Law No. 5 of 1986 concerning PTUN, and Law No. 28 of 2007 concerning General Provisions and Procedures Taxation. The discrepancy between the Tax Court Law and Law No. 28 the Year 2007 is a matter of requirements for filing an appeal. Based on Article 36 paragraph (4) of the Tax Court Law, an appeal may only be made if the taxpayer who is going to appeal is required to have paid $50 \%$ of the disputed tax debt. The provision that determines that taxpayers must pay $50 \%$ of the amount of tax owed to file an appeal from the aspect of justice is proof of the imbalance of the taxpayer and the tax authorities in a case in the Tax Court. Taxpayers (appellants) have a weaker position than the tax authorities because of the compulsion to pay $50 \%$ of the tax owed amount before a decision on the appeal is filed. The provisions of Article 36 paragraph (4) of the Tax Court Law are out of sync with Article 25 paragraph (10) of Law No. 28 of 2007 concerning Amendments to Law No. 6 of 1983 concerning General Provisions and Tax Procedures. It stipulates that taxpayers do not need to pay $50 \%$ of the amount of tax payable before filing an appeal. However, if the appeal is rejected or partially granted, the taxpayer will be subject to a fine.

The findings also showed that in comparison, in general, in settling tax disputes through the judiciary, there are appeal and cassation efforts in some countries, for example, the United States, the Netherlands, Canada, South Korea, Japan, Malaysia (Pratt \& Kulsrud, 2011; Ispriyarso \& Saadah, 2019; 
Roisah et al., 2020). Settlement of tax disputes through judicial institutions in various countries such as the United States (Lederman, 2014), Canada (Arnold, 2019), South Korea (Yun, 2003), Japan (Nakayama, 2007), and Malaysia (Kasipillai, 2000) shows that there are efforts to appeal and cassation.

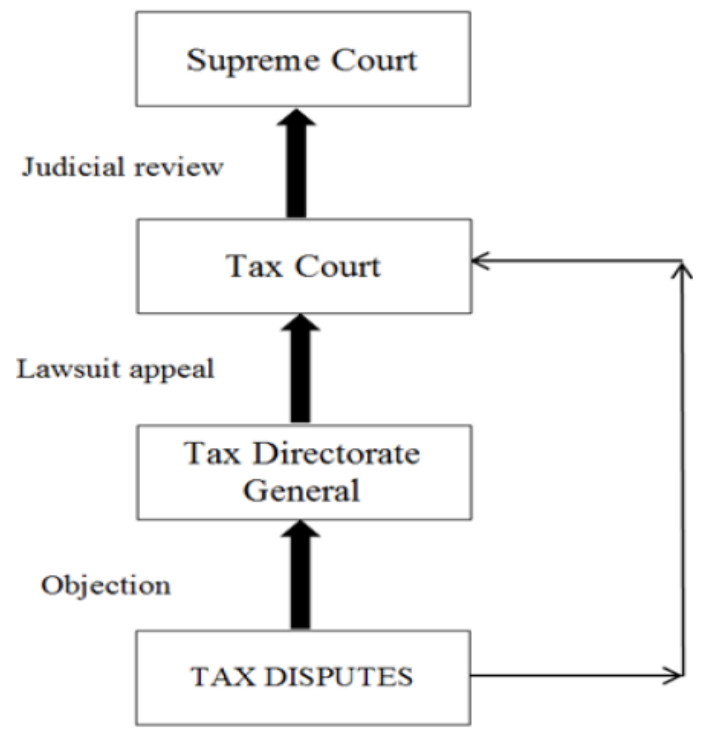

Figure 1: Tax Dispute Resolution based on Law No. 14 of 2002.

Meanwhile, in Indonesia, there are no appeals and cassations in the settlement of tax disputes through the judiciary. The Tax Court decision in Indonesia is a final level decision, and legal remedies cannot be made against the decision of the Tax Court except through a Reconsideration. The settlement of tax disputes in Indonesia based on Law No. 14 of 2002 is shown in Figure 1.

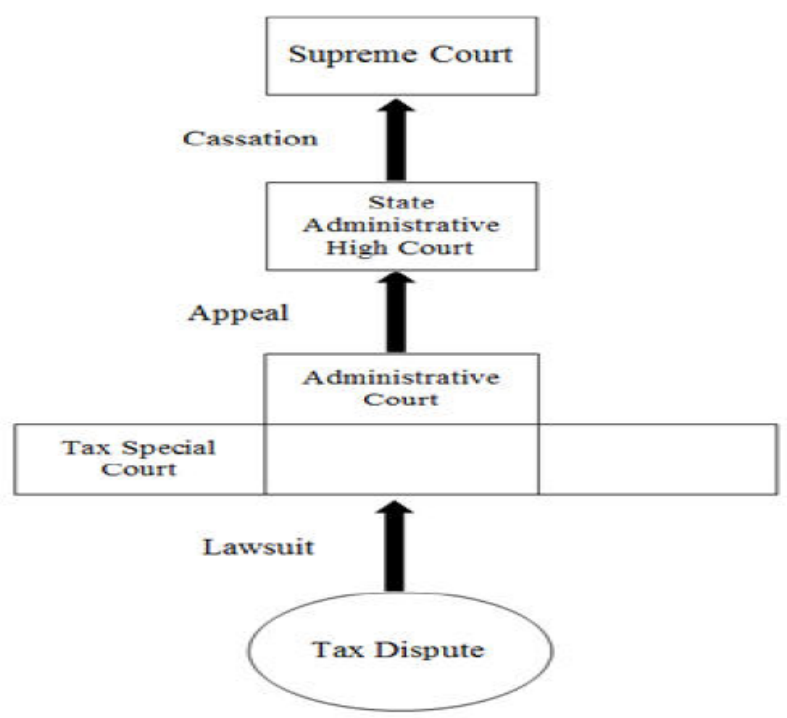

Figure 2: Tax Dispute Resolution as a Special Court in the State Administrative Court.
Settlement of tax disputes based on Law No. 14 of 2002 must be changed after the Tax Court becomes a Special Court within the State Administrative Court. After the position of the Tax Court as a Special Court for the State Administrative Court, it should be necessary to immediately formulate a model for settling tax disputes as a Special Court for the State Administrative Court, as shown in Figure 2.

\section{DISCUSSION}

The findings highlight that legal reform is related to the aspect of eliminating the dualism of the Tax Court supervision. As it is established in Article 5 of Law No. 14 of 2002, it has been decided that supervision on Tax Courts in Indonesia including technical oversight for the judiciary go to the Supreme Court, while organizational, administrative, and fiscal supervision is under the Ministry of Finance. This is a dualism of supervision and contradicts the Judicial Power Law. Furthermore, the dualism of the Tax Court harms tax justice. This condition can show from the Tax Court Independence and Tax Court Performance. Correspondingly, eliminating dualism of supervision in the Tax Court is by uniting both the technical supervision of the judiciary and the organizational, administrative, and financial fostering carried out by the Supreme Court. The court supervision conducted by the Supreme Court may include technical supervision as well as organizational, administrative, and financial guidance which supervise easier.

Moreover, it is needed to increase the number of tax courts in the regions. The domicile of the Tax Court is the only one in Jakarta, which is a form of injustice against taxpayers who will seek justice in a Tax Court where their domiciles are far from Jakarta. For those who go law in court is very costly. This condition becomes certainly burdensome for taxpayers who want to go law in the Tax Court, especially for taxpayers with financial incapability. Though the Tax Procedure Court does not oblige the taxpayers present, taxpayers may attend if only needed. Also, the Tax Dispute settlement process through the Tax Court only obliges the counterpart or the defendant present, because the appealing applicant or the plaintiff, may attend the trial of his wish, except being summoned by a Judge for certain reasons. Also, this condition makes injustice, because there is an imbalance status between taxpayers and tax authorities in litigation in the Tax Court. Counterpart/defendant (in this case Fiscus) gets an advantage because of the place of the Tax Court in Jakarta where the counterpart/compulsory can attend 
so that they can more freely deliver information at the hearing than the taxpayer. Based on this, it is necessary to immediately reform the Tax Court by forming/holding the Tax- Court in the area. The establishment of a Tax Court in the region comes along with the implementation of fiscal decentralization which gives authority to local governments to collect taxes, there is a tendency for tax disputes in the regions to increase.

On the latest development, on June 7, 2012, a place of trials for tax disputes was founded in Yogyakarta. Now taxpayers in Central Java and Yogyakarta Special Region can undergo tax disputes with the Directorate General of Taxes, and they do not have to undergo a judicial process in Jakarta. Starting on June 7,2012, the Directorate General of Taxes in Yogyakarta has opened the first Tax The court outside Jakarta. This Tax Court in Yogyakarta became an extension of Jakarta. Tax Court aims to ease taxpayers in Central Java and Yogyakarta who undergo tax disputes.

For the sake of realizing legal certainty regarding the tax tribunal in the future, it is necessary to immediately synchronize both vertically and horizontally between the Tax Court Law and other laws. In addition to the inconsistency between the provisions of the Tax Court Law with other statutory provisions, it is also necessary to improve the provisions of the Tax Court Law relating to the balance of position between taxpayers and the government in litigating cases at the Tax Court. Provisions that need to be improved are taxpayers and the government in court at the Tax Court. This imbalance occurs because the taxpayer does not have to be present at the trial. Simultaneously, the government/fiscus as the defendant or appealed must be present at the trial so that it is more flexible to provide information. Other improvements that need to be made to the provisions of the Tax Court Law are related to judges' recruitment at the Tax Court. The number of judges in the tax court is not proportional to the number of cases that must be resolved. The number of judges in the Tax Court is only 50 people, while the number of cases that enter the number reaches thousands every year so that the cases that are successfully decided are around 30$40 \%$.

Other provisions of the Tax Court Law that need to be amended are the provisions relating to the stages/levels of tax dispute settlement at the Tax Court. Based on the Tax Court Law (especially Article
33 paragraph 1), the Tax Court does not recognize court stages; the Tax Court is the first and last court of tax disputes. The only legal remedy that the parties can take if they are not satisfied with the Tax Court's decision is the extraordinary legal remedy as regulated in Article 77 paragraph (3) of the Tax Court Law. The article determines that disputing parties can submit a review of the Tax Court's decision to the Supreme Court. Settlement of tax disputes at the Tax Court, which does not recognize appeal and cassation, is not following Indonesia's judicial system. Indonesia's justice system has four levels, namely, lawsuit, appeal, cassation, and reconsideration. The provisions for settling tax disputes at the tax court must be changed, mainly based on the new Basic Law's provisions on judicial power; the Tax Court is included as a Special Court within the State Administrative Court (Sa'adah, 2015).

\section{CONCLUSION}

The findings show that the tax courts in Indonesia still have many weaknesses. These weaknesses include the uncertainty of the position of the Tax Court in the judicial system in Indonesia, the absence of appeals and cassations, the dualism of the tax court's position, weak supervision, the unbalanced position of the parties in the tax court, and so on. Therefore, the tax court in Indonesia must be reformed immediately.

Reform of the tax court in Indonesia is carried out through reforms from institutional aspects, legislative aspects, and legal culture. Reform from the institutional aspect that has been carried out is by placing the tax court as a special court within the state administrative court. This is technically then followed up with a further arrangement whereby the proceedings are changed following the tax court as a special court in the state administrative court. From the statutory aspect, synchronization is carried out with other laws both horizontally and vertically. From the aspect of legal culture, increasing morale towards parties related to taxation, both taxpayers and tax officials, including law enforcers.

The findings in this study highlight that at this time, there are no appeal and cassation legal remedies in the settlement of tax disputes in Indonesia. Therefore, in this study, a tax dispute settlement model is prepared after the tax court is included as a special court within the state administrative court. Furthermore, this finding encourages the current Tax Court Law to be amended immediately. Furthermore, it is hoped that 
this research will become the basis for further research on the tax court proceeding model.

\section{REFERENCES}

Afdol, A., \& Setjoatmadja, S. (2015). Position, Existence and Independence of the Tax Court in Judicial Power in Indonesia. Jurnal Hukum Bisnis, 1(1).

Arnold, B. J., Ault, H. J., \& Cooper, G. (Eds.). (2019). Comparative Income Taxation: a Structural Analysis. Kluwer Law International BV.

Bruno, R. L. (2019). Tax enforcement, tax compliance and tax morale in transition economies: A theoretical model. European Journal of Political Economy, 56, 193-211. https://doi.org/10.1016/j.ejpoleco.2018.08.006

Filippin, A., Fiorio, C. V., \& Viviano, E. (2013). The effect of tax enforcement on tax morale. European Journal of Political Economy, 32, 320-331. https://doi.org/10.1016/j.ejpoleco.2013.09.005

Friedman, L. M. (1975). The legal system: A social science perspective. Russell Sage Foundation.

Horodnic, I. A. (2018). Tax morale and institutional theory: a systematic review. International Journal of Sociology and Social Policy, 38(9/10), 868-886. https://doi.org/10.1108/lJSSP-03-2018-0039

Indarti, E. (2020). Strengthen security and public order: Accountability management in improving the quality of law enforcement. Academic Journal of Interdisciplinary Studies 9(2), 82-88. https://doi.org/10.36941/ajis-2020-0025

Ispriyarso, B. (2015). Weaknesses of Tax Court In Indonesia from the Aspects of Legal Certainty and Justice. Proceeding Kuala Lumpur International Business, Economics and Law Conference 6, Vol. 4. April 18 - 19, 2015, Hotel Putra, Kuala Lumpur, Malaysia.

Ispriyarso, B., \& Saadah, N. (2019). Independence and procedures of tax dispute resolution institutions in Indonesia and East Asian countries. International Journal of Innovation, Creativity and Change 10(2), 109-117.

Juli, W., \& Sariono, J. N. (2014). Hak dan Kewajiban Wajib Pajak dalam Penyelesaian Sengketa Perpajakan di Pengadilan Pajak. Jurnal Perspektif, 19(3). https://doi.org/10.30742/perspektif.v19i3.21
Kasipillai, J. (2000). A Practical Guide to Malaysian Taxation: Current Year Assessment. McGraw-Hill.

Lederman, L. (2013). (Un) appealing deference to the Tax Court. Duke LJ, 63, 1835.

Nakayama, K. (2007). Resolution of Tax Disputes in Japan. Bulletin For International Taxation, 61(9/10), 459.

Pratt, J., \& Kulsrud, W. (2011). Federal Taxation. Cengage Learning.

Pudyatmoko, Y. S. (2013). Courts and tax dispute resolution. Jakarta: Gramedia Pustaka Utama.

Ridwan, H. R. (2011). State administrative law. Jakarta: Raja Grafindo Persada.

Roisah, K., Utama, Y.J., Saraswati, R., \& Whidari, Y. (2020). Status and contemporary development of employee inventions ownership in G-20 countries. European Research Studies Journal, 21(2), 214-224. https://doi.org/10.35808/ersj/996

Rumadan, I. (2012). Eksistensi Pengadilan Pajak dalam Sistem Peradilan di Indonesia. Jurnal Hukum dan Peradilan, 1(1) 35-62. https://doi.org/10.25216/JHP.1.1.2012.35-62

Sa'adah, N. (2015). Building a Tax Justice System Based on the Principle and Judicial Administration System in an Effort to Provide Legal Protection to the Parties (Doctoral dissertation, Diponegoro University).

Saidi, M. D. (2011). Tax Law Update. Jakarta: Raja Grafindo Persada

Saraswati, R., Ristyawati, A., \& Basworo, R.S. (2020). Recent developments and changes in the governance of regional legal products in Indonesia: Supervision, evaluation and clarification mechanisms. International Journal of Innovation, Creativity and Change 12(7), 1-9.

Soemitro, R. (1977). Fundamentals of Tax Law and Income Tax. Bandung: Eresco.

Tyesta, L.A.L.W., Saraswati, R., \& Arif, F. (2020). Implications of legal positivism of the promotion of children's rights on national law. Journal of Advanced Research in Law and Economics, 11(2), 661-666. https://doi.org/10.14505/jarle.v11.2(48).36

Yun, S. R. (2003). South Korea: Tax Controversies. Asia Pasific Tax Bulletin, 8(9), 259.

Received on 25-02-2021

Accepted on 30-03-2021

Published on 05-04-2021

https://doi.org/10.6000/1929-4409.2021.10.86

(C) 2021 Ispriyarso et al.; Licensee Lifescience Global.

This is an open access article licensed under the terms of the Creative Commons Attribution Non-Commercial License (http://creativecommons.org/licenses/by-nc/3.0/) which permits unrestricted, non-commercial use, distribution and reproduction in any medium, provided the work is properly cited. 